\title{
Tulareminin Serolojik Tanısı İçin In House Enzyme- Linked Immunosorbent Assay (ELISA) Prototipi ve Mikroaglütinasyon Test (MAT) Antijeninin Geliştirilmesi \\ - Sevil ERDENLİĞ GÜRBíLEK ${ }^{1}$, $\odot$ Osman Yaşar TEL ${ }^{1 *}$, ๑ Ayfer GÜLLÜ YÜCETEPE ${ }^{1}, \oplus$ Oktay KESKİN ${ }^{1}$
}

1Harran Üniversitesi Veteriner Fakültesi Mikrobiyoloji Anabilim Dalı Eyyübiye Kampüsü, Eyyübiye, Şanlıurfa, TÜRKİYE

Received 17-12-2020 Accepted 04-05-2021

\begin{abstract}
Özet
Bu çalışmada, Francisella tularensis (F. tularensis)'e karşı gelişen antikorları saptamak için bir Enzyme- Linked Immunosorbent Assay (ELISA) prototipi ve kristal viyole boyalı bir mikroaglütinasyon test (MAT) antijeni geliştirildi. Ayrıca konfirme edici Western blot (WB) tekniği de serumlara uygulandı. Alınan sonuçlara göre MAT, ELISA ve WB testlerinin tanısal duyarlılıkları \%100 olarak bulunurken, özgüllükleri sırası ile \%100, \%98 ve \%96 olarak bulundu. Geliştirilen MAT ve ELISA ile 72 insan serumunda seropozitiflik oranı her iki teste de \%4.2 olarak bulunurken, 190 koyun serumunda MAT ve ELISA seropozitifliği sırası ile \%3.2 ve \%4.7 olarak bulundu. Alınan sonuçlara göre ülkemizde tularemi insan ve hayvanlarda varlığını sürdüren bir infeksiyondur. Ancak daha sağlıklı epidemiyolojik yorum yapabilmek için daha çok sayıda seruma ve farklı hayvan türleri ile çalışılmasına ihtiyaç bulunmaktadır. Sonuç olarak, ELISA ve konfirme edici Western blotting kombinasyonunun tulareminin serolojik tanısında kullanılabilecek uygun bir kombinasyon olduğu düşünülmektedir. Anahtar Kelimeler: F. tularensis, MAT, ELISA, Western blot.
\end{abstract}

\section{Abstract \\ Development of an in House Enzyme- Linked Immunosorbent Assay (ELISA) Prototype and Microagglutination Test (MAT) Antigen for Serological Diagnosis of Tularemia}

In this study, a microagglutination test (MAT) antigen stained by crystal violet and an in house Enzyme- Linked Immunosorbent Assay (ELISA) prototip were developed in order to detect antibodies against Francisella tularensis. Besides, Western blot technnique was used as the confirmatory test. According to the results, diagnostic sensitivity of MAT, ELISA and WB was 100\%, while diagnostic specificities of these tests were $100 \%, 98 \%$ and $96 \%$, respectively. Seropositivity rates of serum samples taken from 72 human were $4.2 \%$ for both tests. Seropositivity rates of 190 serum samples from sheep were 3.2\% for MAT and 4.7\% for ELISA. Results seem that tularemia exists in both humans and in animals. However, in order to make more definitive evaluation about the disease, more serum samples taken from various animal species are needed to be tested for this disease. As conclusion, it was thought that ELISA and confirmatory Western blot will be suitable combination for serologic diagnosis of tularemia.

Key Words: F. tularensis, MAT, ELISA, Western blot

\section{Giriş}

Tularemi, başta kemiriciler olmak üzere hayvanlarda patojenik olan ve ayrıca hayvanlardan insanlara geçerek farklı klinik tablolar oluşturan Francisella tularensis (F. tularen- sis)'in neden olduğu zoonotik bir hastalıktır. Bakterinin doğal rezervuarları genellikle kemirici hayvanlardır. Bakteri, kemiricilerden bulaşarak ya da kene, sinek, sivrisinek gibi kan emici artropodlarla taşınarak doğada döngüsünü sürdürmektedir. Bazı kene türleri vektör olmak yanın-

\footnotetext{
* Corresponding author: Harran Üniversitesi Veteriner Fakültesi Mikrobiyoloji Anabilim Dalı Eyyübiye Kampüsü, ŞANLIURFA
} GSM: +90 5072356961 Tel: +90 4143183941 e-posta: oyasar@gmail.com 
da etkeni aylarca vücudunda taşır. Etkenin rezervuar ve vektörleri bölgeden bölgeye farklılık gösterebilir. ${ }^{1}$ Hastalığın yeterince tanınmaması ve bildirim eksikliği nedeniyle dünyada tularemi insidansı tam olarak bilinmemektedir. ${ }^{2}$ Türkiye’deki duruma bakıldığında, tulareminin 2005 yılı öncesinde Marmara ve batı Karadeniz Bölgelerinde yaygın olmasına rağmen, 2009-2010 yıllarının ilk yarısında özellikle İç Anadolu Bölgesi olmak üzere diğer bölgelerden yeni vakalar rapor edildiği bildirilmiştir. ${ }^{3}$ Evcil çiftlik hayvanları arasında tularemiye en duyarlı tür koyunlardır ve hastalık koyunlarda kene enfestasyonlarına bağlı olarak mevsimsel bir özellik gösterir. Ancak hastalık kedi, tavşan, köpek, domuz ve atlarda da bildirilmiştir. Sığırların ise genellikle hastalığa dirençli olduğu bilinmektedir.

Hastalığın klinik teşhisi zordur. Teşhis için laboratuvar muayeneleri gereklidir. Ancak F. tularensis laboratuvar bulaşması yönünden çok dikkatli olunması gereken bir etkendir. Eğer laboratuvar ortamında canlı bakteri ile çalış1lıyorsa biyogüvenlik düzeyi III, şüpheli örneklerle çalış1lıyorsa biyogüvenlik II düzeyinde çalışılması zorunludur. ${ }^{4}$ $\mathrm{Bu}$ nedenle seroloji hastalığın tanısında önemli bir tanısal araç olarak kullanılmaktadır. F. tularensis’e karşı gelişen antikorlar aglutinasyon ve ELISA yöntemiyle saptanabilmektedir. ${ }^{5-8}$ Uzun yıllar etkene karşı gelişen antikorları saptamak amacıyla tüp aglutinasyon (TA) testi kullanılmıştır. ${ }^{5,7,9}$ Ancak TA testinin zaman alıcı olması, çok sayıda örneğin incelenmesine uygun olmaması ve tüketilen antijen miktarının fazlalığı gibi dezavantajları nedeniyle 1970’li yıllardan itibaren mikroaglutinasyon (MA) testi kullanılmaya başlanmıştır ${ }^{10-14}$ Günümüzde MA test antijenin ticari olarak üretilmemesi nedeniyle "in-house" olarak hazırlanmaktadır ve belirli bir standardizasyonu bulunmamaktadır. ${ }^{13,14,18}$ Bu çalışmada, insanlarda ve hayvanlarda tulareminin serolojik tanısında kullanılacak güvenilir sonuçlar veren MAT antijeni ve duyarlılığı ve özgüllüğ̈ü yüksek bir ELISA prototipinin geliştirilmesi amaçland.

\section{Materyal ve Metot}

Araştırmaya Harran Üniversitesi Hayvan Deneyleri Yerel Etik Kurulu (HRÜ-HADYEK) tarafından 26.03.2018 tarih ve 2018/003 nolu oturumun 01-02 nolu kararinca onay alınmıştır.

Bakteriyel suş ve referans MAT antijeni: F.tularensis LVS aşı suşu (ATCC 29648) Kocaeli Üniversitesi Tip Fakültesi, Tıbbi Mikrobiyoloji Anabilim Dalı Öğretim üyesi Prof. Dr. Aynur Karadenizli'den temin edildi. Temin edilen suş, içine \%2 hemoglobin (Oxoid) solüsyonu içeren Cystine Kalp agarda (Difco) \%5 CO2 içeren inkübatörde üretildi. Referans MAT antijeni Türkiye Halk Sağlığı Kurumu, Ulusal Tularemi Referans Laboratuvarindan temin edildi.

Pozitif ve negatif kontrol serumları: Mikroaglütinaston tes- ti (MAT) sonuçları belli olan tularemi pozitif insanlara ait standart serumlar ve referans MAT antijeni, Türkiye Halk Sağlığı Kurumu, Ulusal Tularemi Referans Laboratuvarı temin edildi. Bu serumların titreleri, 1:20, 1:80, 1:160, 1:640 ve 1:1280 idi. Bu serumlar çalışmada yapılacak MAT antijeni, ELISA ve Western blot testinde pozitif kontrol serumları olarak kullanıldı. Laboratuvarımız serum stoklarında bulunan ve referans MAT antijeni ile negatif bulunan, brucellosis yönünden de negatif olan insan serumları çalışmada negatif kontrol serumları olarak kullanıldı. Geliştirilen "in house" ELISA ve MAT antijeni, koyunlardaki seropozitifliğin saptanması amacı ile bölgedeki yetiştiriciler tarafından daha önceden anabilim dalımıza teşhis amacıyla getirilen ve halen derin dondurucuda saklanan koyun serum örnekleri kullanıldı. Ayrıca laboratuvar stoklarımızda bulunan Brucellosis negatif insan serumlarından 72 adedi tularemi yönünden ELISA ile test edilmek için kullanıldı. Laboratuvarımız serum stoklarında bulunan brucellosis yönünden pozitif insan serumu olası bir çapraz reaksiyonu değerlendirmek amacı ile kullanıldı.

MAT antijenin hazırlanması: MAT antijeninin hazırlanmasında Brown ve ark. ${ }^{10}$ bildirdiği yöntem, bazı modifikasyonlar yapılarak uygulandı. Bu amaçla, \% 2 hemoglobin solüsyonu içeren Sistein kalp agarda üreyen F. tularensis subsp holarctica LVS aşı suşu 5-6 günlük olduktan sonra yüzeyindeki koloniler $\% 0.85 \mathrm{NaCl}$ ve $\% 0.5$ formalin içeren FFTS içinde toplanarak stok antijen solüsyonu hazırlandı. Bu solüsyon yine aynı dilüent ile iki kez yıkanarak santrifüj edildikten sonra sediment kendi hacminin 5 katı FFTS ile süspanse edilerek $+4{ }^{\circ} \mathrm{C}$ ye stok MAT antijeni olarak kaldırıldı. MAT antijeninin boyanması için kristal viyole, safranin $\mathrm{O}$ ve malaşit yeşili olmak üzere üç ayrı boyanın kullanılabilirliği araştırıldı. Bunun için, reaksiyonun en rahat şekilde okunabildiği ve referans MAT antijeninin sonuçları ile paralellik gösteren antijen ve boyanın optimum konsantrasyonları belirlendi. MAT: Üretilen MAT antijeni ile tularemi yönünden referans pozitif serumlara, negatif serumlara ve brucellosis yönünden pozitif olan insan serumlarına standart prosedürlere göre MAT yapıldı. ${ }^{10} \mathrm{Bu}$ amaçla çukur tabanlı ELISA dilüsyon pleytleri kullanıldı. Serumun titresi aglütinasyonun görüldüğü en son çukura tekabül eden serum sulandırması olarak kabul edildi. Testin titresi 1:20 ve üzeri olduğunda pozitif kabul edildi. ELISA antijeninin hazırlanması: Bu amaçla, Yi ve Hackett ${ }^{15}$ bildirmiş olduğu Tri-Reagent yöntemi, modifiye edilerek LPS tabakasının izole edilmesinde kullanıldı. Bu amaçla, Sistin kalp agarda üreyen F.tularensis LVS suşunun kolonileri agar yüzeyinden steril tamponlu tuzlu su (PBS) ile toplandiktan sonra elde edilen kültürler benmari de $80^{\circ} \mathrm{C}$ 'de 30 1sı ile inaktive edildikten sonra ölü bakteri süspansiyonu, $+4^{\circ} \mathrm{C}$ 'de $3.500 \mathrm{rpm}$ ' de santrifüj edilerek üstteki 
besiyeri uzaklaştırıldı ve alttaki ölü bakteri peleti toplandı. Toplanan her bir gram bakteri peleti için $2 \mathrm{ml}$ Tri-reagent kullanıldı. Karışım oda derecesinde 10-15 dakika tam bir homojenizasyon için bekletildi ve bu sürenin sonunda, faz seperasyonu yaratmak için her bir gram bakteri peleti için karışıma $300 \mu \mathrm{l}$ kloroform eklendi. Süspansiyon vortekste hızlıca karıştırılarak 10 dakika daha inkübe edildi ve daha sonra 12.000 g.de 10 dakika süre ile santrifüj edildi. Böylece su ve organik fazlar ayrılacaktır. Su fazı yeni bir 1.5 ml.lik santrifüj tüpüne transfer edildi. Organik fazın üstüne $100 \mu \mathrm{l}$ distile su eklenerek karışım tekrar 12.000 g.de 10 dakika daha santrifüj edildi. Su fazı bir önceki su fazı ile kombine edilerek elde edilen bu ham LPS çözeltisi $-20^{\circ} \mathrm{C}$ de daha sonra ELISA solid faz antijeni olarak kullanılmak üzere saklandı.

ELISA: İzole edilen antijenin çeşitli konsantrasyonları, MAT 1:1280 titredeki serumun çeşitli dilüsyonları ile karşılıklı titrasyonları (checkerboard analizi) yapıldıktan sonra belirlenen en uygun antijen konsantrasyonu, karbonat-bikarbonat buffer ( $\mathrm{pH}$ 9.6) kaplama solüsyonu içinde sulandırılarak 96 gözlü pleytin (NUNC, 269620, Denmark) her kuyucuğuna $100 \mu$ l olarak konuldu. Antijenle kaplanan pleytler bir gece $4{ }^{\circ} \mathrm{C}$ de beklediler. PBS solüsyonuna eklenen \% 0.5 Tween 20 ile hazırlanan (PBS-T) pleytlerin $4 \mathrm{kez}$ yıkanmasından sonra pozitif ve negatif serumlar ve laboratuvarımız serum koleksiyonunda bulunan serumlardan 72 insan ve 190 koyun test serumu 1:100 oranında dilüye edilerek pleyt kuyucuklarına primer antikor olarak $100 \mu \mathrm{l}$ konuldu ve yıkama işleminin ardından HRPO ile işaretli rekombinant A/G konjugatı (Pierce 32490) PBST-T içinde 1:20.000 oranında dilüye edilerek eklendi. Yıkama işlemlerinin ardından üzerine $100 \mu \mathrm{l}$ kromojenik substrat $(0.1 \mathrm{M}$ sitrat tamponu ( $\mathrm{pH}$ 5.5) içinde $2 \mu \mathrm{g}$ ortho-phenylenediamine ve $\% 0.03 \mathrm{H} 2 \mathrm{O} 2$ ) ilave edildi. Pleytler oda ssisinda 10 ila 15 dakika bekletildikten sonra reaksiyonu durdurmak için her kuyucuğa $100 \mu \mathrm{l} 4 \mathrm{~N} \mathrm{H} 2 \mathrm{SO} 4$ ilave edilerek pleytlerin otomatik ELISA okuyucusu (VERSAmax 3.13/B2573) ile 490 nm'de absorbans değerleri okundu. Negatif serum OD'lerin ortalaması artı 3 standart deviasyon (SD) ELISA eşik değeri olarak belirlendi. Referans pozitif serumların her birine $10 \mathrm{kez}$, negatif serumların her birine $5 \mathrm{kez}$ ve brucellosis yönünden pozitif olan insan serumlarına da 10 kez ELISA uygulanarak ortalaması ve standart sapması alındı. Geliştirilen ELISA prototipinin duyarlılığı, (Gerçek Pozitif Sayısı)/(Gerçek Pozitif Sayısı+Yanlış Negatif Sayısı) X 100; özgüllügü (Gerçek Negatif Sayısı)/(Gerçek Negatif Sayısı+Yanlış Pozitif Sayısı) X 100 formülleri ile hesaplandi.

\section{Sodyum dodesil sülfat poliakrilamit jel elektroforesiz (SDS-PAGE):}

SDS-PAGE elektroforezis standart yöntemlere göre uyguland $1{ }^{16}$ F.tularensis'in üreyen kültürlerinden iki farklı antijen hazırlanarak SDS-PAGE ve Western blot tekniğinde kullanıldı. Bunlardan birincisi ELISA için kullanılan kısmı purifiye lipopolisakkarit (LPS) antijen ve diğeri tüm hücre lizatı (THL) şeklinde hazırlandı. THL hazırlanmasında, antijen FFTS içinde toplanıp bu solüsyonda $3 \mathrm{kez}$ yıkanıp santrifüj edildikten sonra altta oluşan hücre peleti, tris tamponlama çözeltisi (TBS-T) $(0,15 \mathrm{M} \mathrm{NaCl}, 0.050 \mathrm{M}$ Tris-HCl, \%1 Tween 20) ile 1:4 oranında karıştırıldı. Bu karışımdan üç kısım, 5 kısım Laemmli buffer (500mM Tris/ $\mathrm{HCl} \mathrm{pH} \mathrm{6.8;} \mathrm{\%} 4$ (w/v SDS; \% 10 (v/v gliserol; \% 10 (v/v) 2 - $\beta$-merkaptoetanol ve \% 0.004 bromfenol mavisi) ile karıştırıldıktan sonra steril ependorf tüplerine konuldu ve 5 dakika süre ile kaynatıldı. LPS antijeni ise Laemmli buffer ile 1:3 oranında karıştırıldıktan sonra kaynatıldı. Kaynat1lıp soğutulan örnekler daha sonra tek büyük bir kuyuya $150 \mu$ l olarak yüklendi. Protein ladder olarak Spectra Multicolor Broad Range Protein Ladder (Thermo Scientific, Lot 00655455) kullanılarak büyük kuyunun yanındaki küçük kuyucuğa $10 \mu \mathrm{l}$ olarak yüklendi. Örneklerdeki proteinler \%12 homojen akrilamit ayırıcı (resolving) jel ve \% 4 akrilamit yükleme (stacking) jeli ile standart yöntemlere göre sabit 100V akımda ayrıştırıldılar. (EC 120 mini vertikal jel sistemi).

\section{Western blot testi:}

Elektroforez ile ayrılan proteinlerin immünolojik olarak saptanması Towbin ve ark. ${ }^{17}$ bildirdiği yönteme göre yapıldı. Moleküler standart olarak transfer sonrası nitroselluloz membranda herhangi bir saptama işlemi yapılmaksızin gözlemlenen Spectra Multicolor Broad Range Protein Ladder (Thermo Scientific) kullanıldı. Antijenler yukarıda bahsedildiği şekilde SDS-PAGE ile ayrıştırıldıktan sonra $0.2 \mu \mathrm{m}$ por çaplı nitroseluloz membrana (NM) (Sigma) $20 \mathrm{~V}$ sabit akımda 1.5 saat süreyle standart yöntemlere göre transfer edildiler (EC 140 Mini Blot Module). NM, kapatma (blocking) çözeltisi ile (TBS-T) çözeltisinde hazırlanmış \% 5 yağsız süt tozu (BLOTTO) ve $\% 0.02$ sodium azide) bloklandıktan sonra strip tarzında şerit olarak kesildi. Şeritler yıkama solusyonunda (TBS-\% 0.2 Tween 20) y1kandiktan sonra primer antikor olarak pozitif referans serumların $1 / 200$ oranında ve negatif serumun $1 / 50$ oranında dilusyon çözeltisinde (TBS; \% 1 süt tozu; \% 0.2 Tween 20) 1 saat süre ile inkübe edildiler. İnkübasyonun sonunda konjugat olarak alkalin fosfataz ile işaretlenmiş Rekombinant A/G proteini (Thermo Scientific, 32391) önerilen dilüsyonda kullanıldı. Yıkama işleminin ardından substrat hazırlandı. Bu amaçla, daha önceden hazırlanan BCIP 
(Sigma) solusyonu (\%100 dimetilformamid çözeltisinde 50 $\mathrm{mg} / \mathrm{ml}$ bromo kloro indolil fosfat), NBT (Roche) solusyonu \% 70 dimetilformamid (Sigma) çözeltisinde $50 \mathrm{mg} / \mathrm{ml}$ nitro blue tetrazolium klorid) ve alkaline fosfataz buffer ( 0.1 M Tris-HCl; 0.1 M NaCl; 5 mM MgCl2 pH 9.5) çözeltileri oda isısına getirildiler. Substratın hazırlanmasında 66 $\mu \mathrm{NBT}$ solusyonu $10 \mathrm{ml}$ AP çözeltisi ile karıştırıldı daha sonra $33 \mu \mathrm{l}$ BCIP çözeltisi eklendi ve oluşan karışım substrat olarak antijen bantların üzerini örtecek şekilde ilave edildi. Bantların gözlenmesinin ardından reaksiyon, distile suyla yapilan yıkama ile durduruldu. Tipik LPS merdiven görüntüsü pozitif olarak kabul edildi.

\section{Bulgular}

Çalışmada reaksiyonların daha rahat okunması ve standart MAT pozitif serumu ile aynı sonucu göstermesi baz alındığında, MAT antijeni üretiminde boya olarak kristal viyole Tablo 1. Test MAT antijeninin standart serumlar ile MAT sonuçları
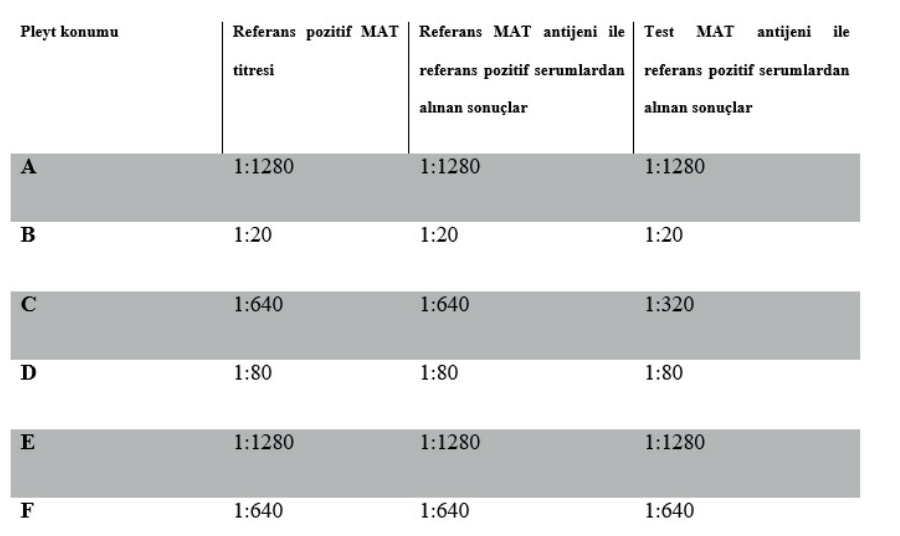

$\begin{array}{llll}\text { G } & 1: 160 & 1: 160 & 1: 160 \\ \text { H } & \text { Brucella+ } & 1: 10 & 1: 10\end{array}$

$1: 1280$

Tablo 3. İnsan ve koyun serumlarının F.tularensis yönünden MAT ve ELISA sonuçları

\begin{tabular}{|c|c|c|c|c|}
\hline \multirow[t]{2}{*}{ serum } & \multicolumn{2}{|l|}{ MAT } & \multicolumn{2}{|l|}{ ELISA } \\
\hline & pozitif & negatif & pozitif & negatif \\
\hline insan & $3(\% 4.2)$ & $69(\% 95.8)$ & $3(\% 4.2)$ & $69(\% 95.8)$ \\
\hline Koyun & $6(\% 3.2)$ & $184(\% 96.8)$ & $9(\% 4.7)$ & $181(\% 95.3)$ \\
\hline
\end{tabular}

seçildi. Ayrıca, kristal viyole ve safranin O, malaşit yeşiline göre bir titre daha ileride sonuç verdi. Üretilen MAT antijeni ile referans pozitif serumların MAT testi yapıldı. Al1nan sonuçlar Tablo 1' de gösterildi. Buna göre tüm pozitif serumlar yeni geliştirilen MAT antijeni ile pozitif bulundugundan testin duyarlılığ $1 \% 100$ olarak bulundu. Brucellosis yönünden pozitif olan serum her iki MAT antijeni ile tan1sal seviyenin altında (1:10) yanıt verdi. Tularemi yönünden referans MAT antijeni ile negatif bulunan 50 negatif serumun tümü geliştirilen yeni MAT antijeni ile negatif bulunduğundan testin özgüllüğ̈̈ \%100 olarak bulundu (veri gösterilmiyor). Tablo 1' de gösterilen sonuçlara göre kristal viyole ile boyanmış MAT antijeninin referans antijenle ve referans pozitif serum titreleri ile benzer sonuç verdiği ve gösterdiği \%100 duyarlık ve özgüllük oranı ile hastalığın tanısında güvenle kullanılabilecek bir test olduğu sonucuna varılarak, testin özgüllük ve duyarlılığının \%100 e yakın olduğunu bildiren bir çok araştırıcı ile benzer sonuçlar alınmıştır.5,10,12,14,18 Geliştirilen ELISA prototipinde eşik değeri 0,284 olarak belirlendi ve belirlenen bu değer baz alınarak, 7 pozitif serumun 10 kez test edilmesi ile elde edilen 70 OD’nin tümü eşik değerinin üstünde olduğundan testin duyarlılığ (sensitivitesi) \%100 olarak bulundu. Testin özgüllüğü test edilen 50 negatif serumun 5 kez test edilmesi ile elde edilen 250 OD'nin 5'i eşik değerinin üstünde bulunduğundan testin özgüllüğü (spesifitesi) \%98 olarak bulundu. Bu çalışmada, laboratuvar stoklarımızda bulunan serumlardan brusellosis yönünden negatif 72 insan serumu ve 190 koyun serumu geliştirdiğimiz ELISA ile test edildiler. Seropozitiflik oranları Tablo 3' de gösterildi. Bu sonuçlara göre insanlarda MAT seropozitiflik \% 4.2 iken koyunlarda \%3.2; insanlarda ELISA pozitiflik yine \%4.2 iken koyunlarda \%4.7 olarak bulundu. WB testinde antijen olarak kısmi purifiye LPS antijeni (Şekil 1) ve tüm hücre lizatı kullanılmıştır (Şekil 2). LPS nin kulanıldığı blot tipik LPS merdiven görüntüsünü verirken tüm hücre lizatının kullanıldığı blotta saptanan protein bantları bu tipik görüntüyü vermedi. Blot $140 \mathrm{kDa}-17 \mathrm{kDa}$ arasında değişen bir takım immunojenik bileşenler gösterdi.

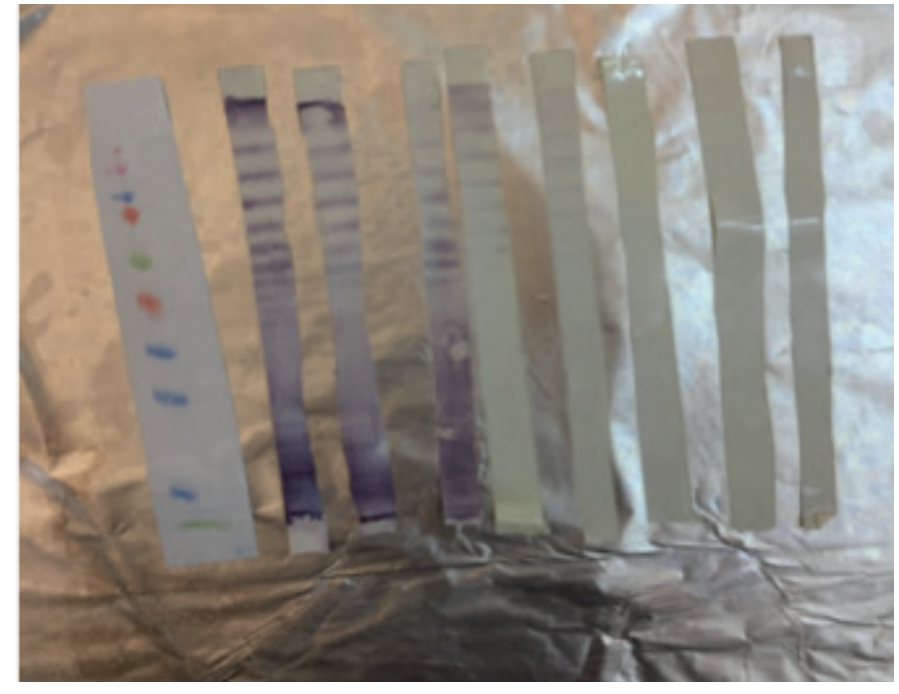

Şekil 1. İnsan serumlarının F.tularensis LPS- Western blot sonuçları 1. Protein ağırlık standartları. 2. 1/1280 tiredeki serum. 3. 1/640 tiredeki serum. 4.1/ 160 titredeki serum. 5. 1/20 tiredeki serum. 6-8 arası negatif insan serumları. 9. Brucella pozitif serum.

WB testinde kullanılan tüm seropozitif serumlar pozitif yanit verirken (\%100 duyarlılık), 50 negatif serumun iki- 
sinde çapraz reaksiyon veren bantların görünmesi (serum örneklerinden biri Şekil 1 de 6. Stripte görülmektedir) ile testin özgüllügü \%96 olarak saptanmıştır.

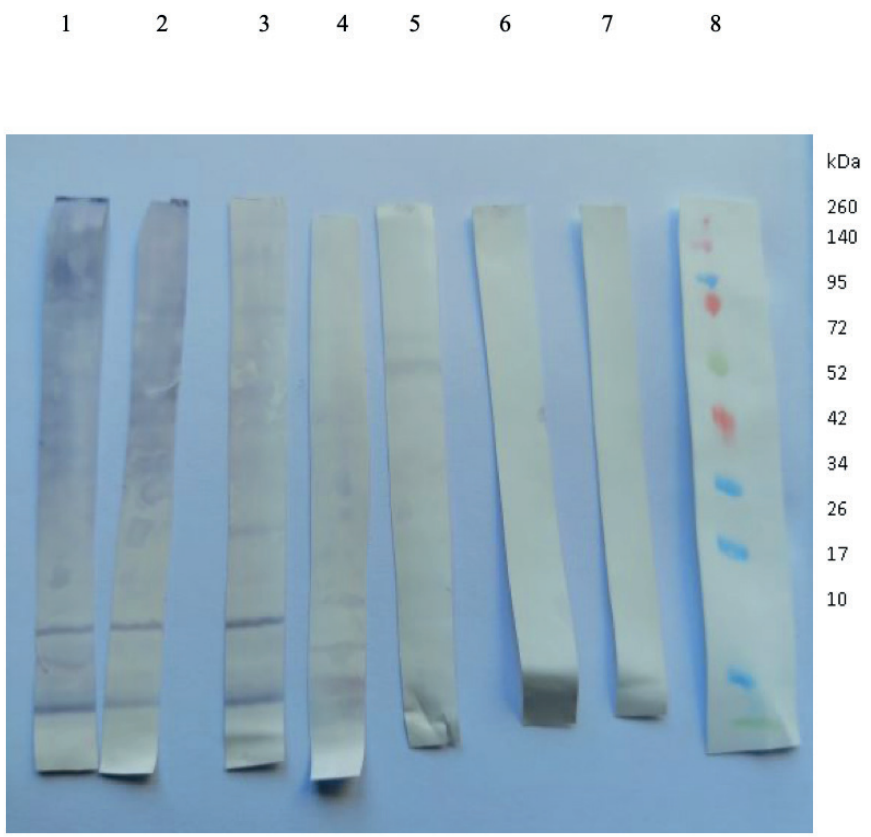

Şekil 2. İnsan serumlarının F.tularensis'in tüm hücre lizatının kullanıldığ1- Western blot sonuçları 1: 1/1280 tiredeki serum. 2:1/640 tiredeki serum. 3:1/160 titredeki serum. 4: Brucella pozitif serum. 5-7: Negatif insan serumları. 8. Protein ağılık standartları

\section{Tartışma}

F.tularensis, infeksiyonun alınma yoluna bakılmaksızın insanlarda ve bazı memeli hayvanlarda çok ciddi ölümcül infeksiyonlar yapan bir ajandır. Yapılan çok sayıda çalışmanın da gösterdiği gibi hastalığın tedavisindeki başarı antibiyotiklerin zamanında verilmesine bağlıdır. Tedavinin 14 günden fazla gecikmesinin çoğunlukla başarısız bir tedavi ile sonuçlandığ 1 bildirilmektedir. ${ }^{19} \mathrm{Bu}$ durum da hastalığın erken güvenli bir tanısının ne kadar hayati bir durum olduğunu ortaya koymaktadır. Hâlihazırda hastalığın teşhisinde en yaygın olarak kullanılan serolojik test MAT'dır. Testin, pratik, kolay uygulanan, ekonomik ve sofistike laboratuvarlara ihtiyaç göstermemesi testin çok geniş çaplı kullanılmasına neden olmuştur. Ancak ülkemizde standardize, ticari bir MAT antijeni yoktur ve laboratuvarlar "in house" olarak ihtiyaç halinde kendi antijenlerini üretmektedirler. Çalışmamızda iki farklı katyonik boya olan kristal viyole ve malaşit yeşili, referans Safranin O boyası ile birlikte kullanılarak MAT antijeni üretildi. Antijen-antikor kompleksinin daha kolay görülmesi için F. tularensis tüm hücre antijeni, bakterinin kimyasal inaktivasyonunu takiben metilen mavisi, kristal moru veya safranin-O ile boyanmaktadır., ${ }^{90,13,14,18}$ Geliştirilen Tetrazolyum Mavisi ile boyanmış F. tularensis MAT antijeninin insan serumları ile standart safranin-O ile boyalı antijenlere göre daha iyi aglutinasyon paterni vermesi ve reaksiyonun daha kolay de- ğerlendirilmesi gibi avantajları olduğunu, elde edilen antijenin doğruluğu, duyarlılığ ve özgüllüğünün \%100 olarak saptandığını bildirmişlerdir.18 Mikroaglutinasyon Testi için Safranin-O-boyalı antijen geliştirmişlerdir. Sato ve ark.14 mikroaglutinasyon testini tüp aglütinasyon testiyle karşılaştırdıkları çalışmada, mikroaglutinasyon testinin tulareminin erken ve spesifik serolojik tanısında yararlı bir araç olduğunu bildirmişlerdir.

Tulareminin serolojik teşhisinde aglütinasyon testlerinin

Tablo 2. Referans serumların ELISA OD değerleri ortalamaları

\begin{tabular}{ll}
\hline Test edilen serum & Ortalama OD \pm Standart sapma \\
\hline F.tularensis MAT 1:20 & $0,63 \pm 0,147$ \\
\hline F.tularensis MAT 1:80 & $0,858 \pm 0,33$ \\
\hline F.tularensis MAT 1:160 & $1,54 \pm 0,22$ \\
\hline F.tularensis MAT 1:640 & $2,65 \pm 0,42$ \\
\hline F.tularensis MAT 1:1280 & $3,02 \pm 0,52$ \\
\hline F.tularensis MAT Negatif & $0,164 \pm 0,04$ \\
\hline Brucella abortus SAT 1:1280 & $0,180 \pm 0,03$ \\
\hline
\end{tabular}

dışında indirekt immunofloresans, ve ELISA gibi testler uygulanmaktadır. Carlsson ve ark. ${ }^{20} \mathrm{~F}$. tularensis'ten elde ettikleri lipopolisakkariti kullandıkları ELISA’nın tüp aglütinasyon testinden $10 \mathrm{kez}$ daha duyarlı olduğunu bildirmişlerdir. Çok sayıda araştırmacı ELISA’nın, hastalığın serolojik teşhisinde rutin olarak en çok uygulanan MAT'dan daha duyarlı olduğunu bildirmektedirler. ${ }^{21-23}$ Dünya sağlık teşkilatı (DSÖ, WHO) kısa sürede sonuç veren ELISA'yı tulareminin serolojik teşhisinde önermektedir. ${ }^{9} \mathrm{Bu}$ çalışmada, ELISA testinin duyarlılığı (sensitivitesi) \%100 olarak bulundu. Testin özgüllüğü test edilen 50 negatif serumun 5 kez test edilmesi ile elde edilen 250 OD’nin 5'i eşik değerinin üstünde bulunduğundan testin özgüllüğü (spesifitesi) \% 98 olarak bulundu. Schmitt ve ark. ${ }^{24}$ kısmen saflaştırılmış lipopolisakkaridlerin antijen olarak kullanıldığ 1 ELISA testinin duyarlılığının \%99 özgüllü̈̆ünün \%97,1 olduğunu bildirmişlerdir. Chaignat ve ark. ${ }^{25}$ ticari ELISA kitleri ile yaptıkları çalışmalarında testin duyarlığını \%94.8-\%97 arasında ve özgüllügünü \%91.5 ve \% 96.8 aralığında bulmuşlardır. Bevanger ve ark.26 OMP ile kapladıkları in house ELISA'da duyarlılı̆̆ı \%95.7 ve özgüllüğü \%96 olarak bulmuşlardır. Porsch -Özçürümez ve ark. ${ }^{13}$ yaptıkları çalışmada ELISA’nın tanısal duyarlılık ve özgüllügü $\% 98$ olarak bulunmuştur. Çalışmanın sonuçları tüm bu araştırıcıların sonuçları ile büyük ölçüde benzerlik göstermekte ve ELISA'yı tanısal duyarlılığı ve özgüllüğü yüksek bir test olarak tanımlanmasına neden olmaktadır. Referans tularemi pozitif serumların her birine $10 \mathrm{kez}$ ve negatif serumların her birine $5 \mathrm{kez}$ ayrıca brucellosis yönünden pozitif olan seruma $10 \mathrm{kez}$ ELISA yapılarak alınan optik dansitelerinin ortalamaları ve standard sapmaları Tablo 2' de gösterildi. 
Alınan sonuçlara göre MAT titreleri ile ELISA OD değerleri arasında serum titrelerine göre yüksek derecede uyum görülmektedir. Bu durumun ELISA sonuçlarından hastanın MAT titresi hakkında bir fikir edinilebileceğini düşündürmektedir.

ELISA’nın arka sinyal oranının düşük olması, pozitif ve negatif OD değerleri arasındaki farkın büyük olması, geliştirilen ELISA prototipinin önemli avantajlarını oluşturmuştur. Brusellosis yönünden pozitif serumun eşik değer altında kalması da çapraz reaksiyonun gözardı edilebilecek minimal bir seviyede olduğunu göstermektedir. Ayrıca ELISA prototipinde sekonder konjugat olarak rekombinant A/GHRPO kullanıldığından bu ELISA ile sadece insanlar değil diğer türdeki hayvanların serolojik teşhisininde yapılabiliyor olması önemli bir sonuçtur. Bu bağlamda laboratuvar stoklarımızda bulunan serumlardan brusellosis yönünden negatif 72 insan serumu ve 190 koyun serumu geliştirdiğimiz ELISA ile test edildiler. Seropozitiflik oranları Tablo 3' de gösterildi.

Enfeksiyonun prevalansını belirlemeye yönelik, evcil hayvanlarda klinik hastalıkların bildirimi ve prevalansına dair bilgiler oldukça kısıtlıdır. ${ }^{27} \mathrm{Bu}$ durum hastalığın hayvanlardaki durumu ve insanlar için oluşturduğu risk faktörlerini sağlıklı bir şekilde değerlendirmeyi sınırlamaktadır. Şeyda T. ${ }^{28}$ Kars il merkezi ve kırsalındaki koyunlarda tularemi seropozitifliği MAT ile \%3,54 ve ELISA ile \%7,8 olarak bulmuştur. Büyük ve ark. ${ }^{29}$ yine Kars Yöresine ait çoban köpekleri ve Ankara Yöresine ait pet köpeklerinde MAT pozitifliği \%4,11 oranında saptamışlardır. Bayram ve ark. ${ }^{30}$ yaptıkları çalışmada insanlar ve o kişilere ait sığır, koyun ve keçilerden aldıkları serumlarda MAT ile pozitiflik araştırmışlardır. Sonuçta insanlarda \%3,6, hayvanlarda ise genel olarak \%9,4 seropozitiflik saptamışlardır. Çeşitli araştırıcıların sonuçları dikkate alındığında çalışmamızda bulunan sonuçlarla büyük benzerlik bulunmaktadır. Ancak Karataş Yeni, ${ }^{31} 5$ farklı yerleşim yerinden topladığ 401 koyun serum örneğinde MAT ile \%27,6 pozitiflik saptamıştır. Çalışmamızda alınan sonuçlarla çok farklı olan bu sonucun nedeni, kullanılan test tekniğine, seropozitiflik olarak kabul edilen titreye, test serumlarının alındığı sürede olası bir salgın durumunun varlığına bağlı olabilir.

Bevanger ve ark ${ }^{21}$ F.tularensis'in diş membran (OM) proteinlerini antijen olarak kullandıklarında WB testinde daha az OM proteinlerini saptamışlar, ancak 12 hastada $43 \mathrm{kDa}$ luk bir antijene kuvvetli bir yanıt aldıklarını bildirmişlerdir. Bizim çalışmamızda $43 \mathrm{kDa}$ luk belirgin bir antijene rastlanılmamış ancak her iki antijenden hazırlanan blotta da 17-26 kDa arasinda kuvvetli reaksiyon veren bantlar saptanmıştır. Antijenin hazırlanma yöntemi ve jele yükleme miktarının da bu farklılıklara neden olabileceği düşünülmüștür. Çalıșmada LPS ile hazırlanan blotta bru- sellosis yönünden müspet olan serum ile bir pozitiflik saptanmazken, tüm hücre lizatı ile olan blotta Brucellosis li serum örneğinde molekül ağırlı̆g küçük olan birkaç bant görülmüştür. Daha çok antijenik komponent içeren tüm hücre lizatında çapraz yanıt verecek antijenik bileşenlerin LPS tabakası ile yapılan blotta göre daha fazla olma ihtimali oldukça mantıklıdır. Bu nedenle konfirme edici WB yapılacağında antijen olarak LPS’yi seçmek olası çapraz reaksiyonları azaltacaktır. WB testinde kullanılan tüm seropozitif serumlar pozitif yanıt verirken (\%100 duyarlılık), 50 negatif serumun ikisinde çapraz reaksiyon veren bantların görünmesi (Serum örneklerinden biri Şekil 1' de 6 . Stripte görülmektedir) ile testin özgüllüğü $\% 96$ olarak saptanmıştır. WB ile ilgili araştırıcıların farklı sonuçlar elde ettiği görülmektedir. Schmitt ve ark. ${ }^{24}$ Western blot testinde ise duyarlılığın \%100 özgüllüğün \%99,6 olduğunu bildirilmişlerdir. Porsch-Özçürümez ve ark, ${ }^{13}$ WB'un tanısal duyarlılık ve özgüllügüünün \% 100 olarak bulmuşlardır. Öbür yandan Chaignat ve ark. ${ }^{25}$ WB'un duyarlılı̆̆ını \% 93.3 ve özgüllüğünü \% 83 olarak bulmuştur. Değerlerdeki farkl1lıkların başlıca antijenin hazırlanması ve saf olup olmadığı ile yakın ilişkisinin bulunduğu düşünülmektedir.

\section{Sonuç}

Sonuç olarak, çalışmada insanlarda ve hayvanlarda tulareminin serolojik tanısında kullanılacak güvenilir sonuçlar veren MAT antijeni ve duyarlılığı ve özgüllüğü yüksek bir ELISA prototipi geliştirilmiştir. Bu testlerin çok daha fazla pozitif ve negatif serumlarla saha validasyonunun yapılmasının, testlerin güvenilirliği, tekrarlanabilirliği açısından büyük bir önemi olacaktır. Geliştirilen bu testlerin zaman zaman insanlarda salgınlar yapan çok önemli bir zoonoz olan ve ülkemizde insanlarda endemik seyreden bu infeksiyonun teşhisine, sahada çeşitli hayvan türlerinde hastalığın yaygınlığının saptanmasına çok büyük yararları olacağı düşünülmektedir.

\section{Teşekkürr}

Bu çalışma, Hr. Ü. Bilimsel Araştırma Projeleri Koordinatörlüğü tarafından 18072 proje numarası ile desteklenmiştir.

\section{Kaynaklar}

1. Çelebi G. Tularemi Sempozyumu, 2004. Erişim Tarihi: 19.03.2018: http://www.klimik.org.tr/ bilgimerkezi/ tularemi/tularemi-yrd-doc-dr-guven-celebi-zonguldak-karaelmas-universitesi-tip-fakultesi-infeksiyon-hastaliklari-ve-klinik-mikrobiyoloji-anabilim-dali/

2. Şahin İ. Tulareminin Bulaş Yolları In: Francisella tularensis ve Tularemi, eds. Gürcan Ş. Nobel Tip Kitabev- 
leri, İstanbul, 2009; 75.

3. Tularemi Hastalığının Kontrolü İçin Saha Rehberi. Erişim Tarihi:11.5.2013. http://sbu.saglik.gov.tr/Ekutuphane/kitaplar/Tularemi\%20Saha\%20Rehberi.pdf.

4. Çelebi B. Tularemi: Laboratuvar tanı, In: III. Zoonotik Hastalıklar Sempozyum Kitabı, Türkiye, 2010; 13-18.

5. Francis E, Evans AC. Agglutination, cross-aggluti-nation, and agglutinin absorption in tularaemia. Public Health Rep. 1926; 41(26): 1273-1295.

6. Kılıç S, Çelebi B, Yeşilyurt M. Evaluation of a commercial immuno-chromatographic assay for the serologic diagnosis of Tularemia. Diagn Microbiol Infect Dis. 2012; 74(1): 1-5.

7. Ransmeier JC, Ewing CL. The agglutination reaction in Tularemia. J Infect Dis. 1941; 69: 193-205.

8. Viljanen MK, Nurmi T, Salminen A. Enzyme-linked immunosorbent assay (ELISA) with bacterial sonicate antigen for $\operatorname{IgM}$, IgA, and IgG antibodies to Francisella tularensis: comparison with bacterial agglutination test and ELISA with lipopolysaccharide antigen. J Infect Dis. 1983; 148(4): 715-720.

9. World Health Organization. WHO guidelines on tularemia. 2007. Geneva, Switzerland. Erişim Tarihi: 19.03.2018. http://www.cdc.gov/tularemia/resources/ whotularemiamanual.pdf

10. Brown SL, Mckinney FT, Klein GC, et al. Evaluation of a safranin-O-stained antigen microagglutination test for Francisella tularensis antibodies. J Clin Microbiol. 1980; 11(2): 146-148.

11. Gaultney JB, Wende RD, Williams RP. Microagglutination procedures for febrile agglutination tests. Appl Microbiol. 1971; 22(4): 635-640.

12. Massey ED, Mangiafico JA. Microagglutination test for detecting and measuring serum agglutinins of Francisella tularensis. Appl Microbiol. 1974; 27(1): 2527.

13. Porsch Özcürümez $M$, Kischel N, Priebe $H$, et al. Comparison of Enzyme-linked immunosorbent assay, Western blotting, microagglutination, indirect immunofluorescence assay, and flow cytometry for serological diagnosis of tularemia. Clin Diagn Lab Immunol. 2004; 11(6): 1008-1015.

14. Sato T, Fujita H, Ohara Y, et al. Microagglutination test for early and specific serodiagnosis of tularemia. J Clin Microbiol. 1990; 28(10): 2372-2374.

15. Yi EC, Hackett M. Rapid isolation method for lipopolysaccharide and lipid A from gram negative bacteria. Analyst. 2000; 125(4): 651-6.

16. Laemmli UK. Cleavage of structural proteins during the assembly of the head of bacteriophage T4. Nature. 1970; 227:680-685.
17. Towbin ST, Staehelin T, Gordon J. Electrophoretic transfer of proteins from polyacrilamide gels to nitrocellulose sheets: procedure and some applications. Proc Natl Acad Sci USA. 1979; 76: 4350-4354.

18. Çelebi B, Kılıç S. Tularemi mikroaglütinasyon testi için tetrazolyum mavisi ile boyalı Francisella tularensis antijeninin geliştirilmesi. Mikrobiyol Bul. 2013; 47(3): 514-522.

19. Çelebi G, Baruönü F, Ayoğlu F, et al. Tularemia, a reemerging disease in northwest Turkey: epidemiological investigation and evaluation of treatment response. Jpn J Infect Dis. 2006; 59: 229-234.

20. Carlsson HE, Lindberg AA, Lindberg G, et al. Enzyme-linked immunosorbent assay for immunological diagnosis of human tularemia. J Clin Microbiol. 1979; 10(5): 615-621.

21. Bevanger L, Maeland JA, Naess AI. Agglutinins and antibodies to Francisella tularensis outer membrane antigens in the early diagnosis of disease during an outbreak of Tularemia. J Clin Microbiol. 1988; 26(3): 433-437.

22. Eliasson H, Olcén P, Sjöstedt A, et al. Kinetics of the immune response associated with Tularemia: comparison of an enzyme-linked immunosorbent assay, a tube agglutination test, and a novel whole-blood lymphocyte stimulation test. Clin Vac Immun. 2008; 15(8): 1238-1243.

23. Splettstoesser W, Guglielmo-Viret V, Seibold E, et al. Evaluation of an immunochromatographic test for rapid and reliable serodiagnosis of human Tularemia and detection of Francisella tularensis-specific antibodies in sera from different mammalian species. J Clin Microbiol, 2010; 48(5): 1629-1634.

24. Schmitt P, Splettstosser W, Porsch Özcürümez ME, et al. A novel screening ELISA and a confirmatory Western blot useful for diagnosis and epidemiological studies of Tularemia. Epidemiol Infect. 2005; 133: 759-766.

25. Chaignat V, Djordjevic-Spasic M, Ruettger A, et al. Performance of seven serological assays for diagnosing Tularemia. BMC Infectious Diseases. 2014; 14: 234-239.

26. Bevanger L, Maeland JA, Naess AI. Competitive enzyme immunoassay for antibodies to a 43,000-molecular-weight Francisella tularensis outer membrane protein for the diagnosis of Tularemia. J Clin Microbiol. 1989; 27(5): 922-926.

27. Otlu S. Hayvanlarda Tularemi araştırmaları ve dünyadaki durum. In: Francisella tularensis ve Tularemi, eds. Gürcan Ş, Nobel Tip Kitabevleri, İstanbul, 2009; 161-168.

28. Şeyda T. Kars bölgesinde koyunlarda Tularemi in- 
feksiyonunun insidensi üzerinde serolojik ve kültürel çalışmalar. Kafkas Üniversitesi Sağlık Bilimleri Doktora Tezi, 1996.

29. Büyük F, Şahin M, Çelebi Ö, et al. Kars ve Ankara yöresine ait köpeklerde Francisella tularensis antikorlarının araştırılması. Turk Hij Den Biyol Derg. 2012; 69(2): 83-88.

30. Bayram Y, Özkaçmaz A, Parlak M, et al. Van ili ve çevresinde risk altındaki insan ve hayvan gruplarında Tularemi seroprevalansı. Mikrobiyol Bul. 2015; 49(4): 532-541.

31. Karataş Yeni D. Francisella tularensıs'in Muhtemel rezervuar hayvanlar ve koyunlarda laboratuvar tanisı. Ankara Üniversitesi Sağlık Bilimleri Doktora Tezi, 2013. 